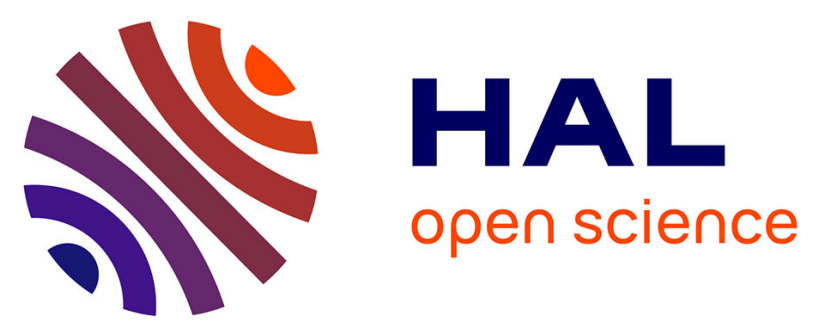

\title{
Thrust-wrench interference tectonics in the Gulf of Cadiz (Africa-Iberia plate boundary in the North-East Atlantic): Insights from analog models
}

João C. Duarte, Filipe M. Rosas, Pedro Terrinha, Marc-André M-A Gutscher, Jacques Malavielle, Sonia Silva, Luis Matias

\section{To cite this version:}

João C. Duarte, Filipe M. Rosas, Pedro Terrinha, Marc-André M-A Gutscher, Jacques Malavielle, et al.. Thrust-wrench interference tectonics in the Gulf of Cadiz (Africa-Iberia plate boundary in the North-East Atlantic): Insights from analog models. Marine Geology, 2011, 289 (1-4), pp.135-149. 10.1016/j.margeo.2011.09.014 . insu-00643630

\section{HAL Id: insu-00643630 \\ https://hal-insu.archives-ouvertes.fr/insu-00643630}

Submitted on 24 Nov 2011

HAL is a multi-disciplinary open access archive for the deposit and dissemination of scientific research documents, whether they are published or not. The documents may come from teaching and research institutions in France or abroad, or from public or private research centers.
L'archive ouverte pluridisciplinaire HAL, est destinée au dépôt et à la diffusion de documents scientifiques de niveau recherche, publiés ou non, émanant des établissements d'enseignement et de recherche français ou étrangers, des laboratoires publics ou privés. 


\section{Thrust - wrench interference tectonics in the Gulf of Cadiz (Africa -}

\section{Iberia plate boundary in the North-East Atlantic): insights from}

\section{analog models}

João C. Duarte ${ }^{\mathrm{a}, \mathrm{b}, \mathrm{c}}$, Filipe M. Rosas ${ }^{\mathrm{a}, \mathrm{b}}$, Pedro Terrinha ${ }^{\mathrm{b}, \mathrm{c}}$, Marc-André Gutscher ${ }^{\mathrm{d}}$, Jacques Malavieille ${ }^{\mathrm{e}}$, Sónia Silva ${ }^{\mathrm{a}, \mathrm{b}, \mathrm{c}}$, Luis Matias ${ }^{\mathrm{f}}$

${ }^{a}$ Instituto Dom Luiz, Campo Grande, Ed. C1, Piso 2, 1749-016 Lisboa, Portugal

${ }^{\mathrm{b}}$ Universidade de Lisboa, Faculdade de Ciências, Departamento de Geologia, Campo

Grande, Ed. C6, Piso 4, 1749-016 Lisboa, Portugal

${ }^{c}$ LNEG, Unidade de Geologia Marinha, Estrada da Portela Zambujal-Alfragide Apartado 7586, 2720-866 Amadora, Portugal

${ }^{\mathrm{d}}$ Université Européene de Bretagne, Brest, IUEM, Domaines Océaniques, UMR6538

CNRS, Univ. Brest, France

${ }^{\mathrm{e}}$ Université Montpellier 2, CNRS UMR 5243, Géosciences Montpellier, 34095

Montpellier cedex 5, France

${ }^{\mathrm{f}}$ Universidade de Lisboa, Faculdade de Ciências, Departamento de Engenharia Geográfica, Geofísica e Energia, Campo Grande, Ed. C8, piso 0, 1749-016 Lisboa, Portugal

\section{Abstract}

In the Gulf of Cadiz key segment of the Africa-Iberia plate boundary (NorthEast Atlantic ocean), three main different modes of tectonic interference between a recently identified wrench system (SWIM) and the Gulf of Cadiz accretionary wedge (GCAW) were tested through analog sand-box modeling: a) An active accretionary 
wedge on top of a pre-existent inactive basement fault; b) An active strike-slip fault cutting a previously formed, inactive, accretionary wedge; and c) Simultaneous activity of both the accretionary wedge and the strike-slip fault. The results we obtained and the comparison with the natural deformation pattern favor a tectonic evolution comprising two main steps: i) the formation of the Gulf of Cadiz Accretionary Wedge on top of inactive, Tethyan-related, basement faults (Middle Miocene to $\sim 1.8 \mathrm{Ma}$ ); ii) subsequent reactivation of these basement faults with dextral strike-slip motion $(\sim 1.8$ Ma to present) simultaneously with continued tectonic accretion in the GCAW. These results exclude the possibility of ongoing active SWIM wrench system cross-cutting an inactive GCAW structure. Our results also support a new interpretation of the SWIM wrench system as fundamentally resulting from strike-slip reactivation of an old (Tethyan -related) plate boundary.

Keywords: SWIM wrench system; Gulf of Cadiz Accretionary Wedge (GCAW); Thrust - wrench interference; Analog modeling; Tethyan-related plate boundary

\section{Introduction}

The Gulf of Cadiz is situated in the North-East Atlantic Ocean, west of the Gibraltar Straights, offshore SW Iberia and NW Morocco (Fig. 1). This zone marks the transition between the Mediterranean Alpine Collision Belt and the Atlantic Azores Gibraltar Fracture Zone (AGFZ; see Fig.1) and corresponds to a segment of the AfricaEurasia plate boundary previously described as tectonically diffuse (e.g. Sartori et al., 1994; Medialdea et al., 2004). Accordingly, a variety of tectonic structures with different orientations, corresponding mostly to W-NW directed thrusts and WNW-ESE 
dextral strike-slip faults (Fig. 1B), are thought to accommodate a WNW-ESE present convergence between Eurasia (Iberia sub-plate) and Africa (Nubia sub-plate) at a rate of ca. 4-5 mm/year (Argus et al., 1989; DeMets et al., 1994; Sella et al., 2002; Calais et al., 2003; Fernandes et al., 2003; Fernandes, 2004; Nocquet and Calais, 2004; Fernandes et al., 2007).

The seismicity of this domain has been characterized as moderate, although several high magnitude historical and instrumental earthquakes are known (e.g. Ms=7.9 28/02/1969 and Mw=6.0,12/02/2007 earthquakes respectively, Fukao, 1973 and Stich et al., 2006, 2007). Among these, the 1755 Great Lisbon Earthquake (estimated magnitude of 8.5 to 8.7; Abe et al, 1979; Johnston, 1996; Martinez-Solares and Arroyo, 2004) triggered a devastating tsunami and destroyed the Portuguese capital (Baptista et al., 1998; Zitellini et al., 2001; Martinez-Solares and Arroyo, 2004). Despite recent mapping updates of the main tectonic structures of this region based on the interpretation of a great variety of newly acquired data (e.g. multi-beam swath bathymetry, reflection and refraction seismics, geodetic; Johnston, 1996, Gonzalez et al., 1996; Zitellini et al., 2001; Gutscher et al., 2002, 2009a,b; Baptista et al., 2003; Gracia et al., 2003a,b; Mulder et al., 2003; Zitellini et al., 2004; Rosas et al., 2009; Terrinha et al., 2009; Zitellini et al., 2009), the precise location of the seismogenic/tsunamigenic source of 1755 major event is still the subject of ongoing debate (e.g. Baptista et al., 1998; Buforn et al., 1988; Zitellini et al., 2001; Gracia et al., 2003a,b; Terrinha et al., 2003; Gutscher, 2004; Gutscher et al., 2006; Terrinha et al., 2009).

In the tectonic map of figure 1B three main sets of structures are immediately recognized: a) several NE-SW striking, westwards directed thrust faults (e.g. Gorringe, Horseshoe and Marquês de Pombal faults); b) major WNW-ESE striking dextral strike- 
slip faults (the SWIM faults) and c) a major thrust bounding the so called Gulf of Cadiz Accretionary Wedge (GCAW frontal thrust). Structures of the first set have previously been described as active and, individually (e.g. Gorringe fault), or together (Marques de Pombal and Horseshoe faults), successively considered and dismissed as possible seismogenic/tsunamigenic sources of the 1755 Great Lisbon Earhquake (e.g. Baptista et al., 1998; Buforn et al., 1988; Zitellini et al., 2001; Terrinha et al., 2009). The other two sets of tectonic structures support the following two fundamental ideas for the interpretation of the Gulf of Cadiz tectonic framework (Gutscher et al., 2002; Zitellini et al., 2009):

- Gutscher et al. (2002), building on previously reported similar ideas (e.g. Royden, 1993 and Lonergan and White, 1997), considered the tectonic evolution of this plate boundary as being dominated by active (roll back) subduction of a retreating east-dipping lithospheric slab, presently positioned beneath the Gibraltar Arc (Fig.1B). Accordingly, associated synthetic accretion of sediments is also reported to occur, represented by the Gulf of Cadiz Accretionary Wedge (GCAW, Fig. 1B), in which several imbricated west-directed active thrusts accommodate on-going shortening.

- Zitellini et al. (2009) argued for the existence of a broad transpressive deformation band, comprising a set of WNW-ESE striking, subvertical, dextral strike-slip faults (SWIM faults in Fig. 1B), which as a whole extend for more than $600 \mathrm{~km}$, from the eastern part of the Gulf of Cadiz to the southern limit of the Gorringe bank. These faults are interpreted by the cited authors as lithospheric faults, and in view of that the SWIM fault system was proposed to 
mark a newly formed plate boundary connecting the AGFZ to the Rif Mountain belt in northern Morocco.

It should be noted that Zitellini et al. (2009) considered the dextral transcurrent SWIM faults in the Gulf of Cadiz as presently active, and cutting the GCAW thrusts, whose activity is considered to be negligible since late Miocene times. Conversely, Gutscher et al. (2002) considered the GCAW thrusts as still active, and as referred above related with present on-going subduction beneath the Gibraltar arc.

In the present work, we test the above assumptions using analog modeling sandbox experiments to model the interference between the two major tectonic systems in the Gulf of Cadiz, i.e. SWIM dextral wrenching and GCAW thrusting, assuming three main different possibilities:

1) The GCAW is presently active and the SWIM faults are thought to correspond to inactive basement faults, inherited from a previous tectonic evolution;

2) The SWIM faults are thought to correspond to major, presently active, dextral strike-slips, cutting a previously formed inactive GCAW;

3) Both tectonic systems are presently active.

Thorough comparison of the obtained results with the observed natural morphotectonic pattern is carried out for each of the above cases. Accordingly, resulting tectonic 
implications for the local and whole scale evolution of this segment of the EurasiaAfrica plate boundary are evaluated and explored.

\section{Morphotectonic characterization of the study area}

The morphology of the Gulf of Cadiz is largely controlled by the main tectonic processes in the area: the thrusting accommodating the GCAW accretion and the wrenching associated to the SWIM fault system. The high-resolution bathymetry of the GCAW shows a west dipping U-shaped body (Figs. 1B and 2A) that extends for more than $250 \mathrm{~km}$ from about longitude $7^{\circ} \mathrm{W}$ to $9^{\circ} 30^{\prime} \mathrm{W}$, with depths ranging from 200 to 4300 meters. It narrows slightly to the west with a width varying from 160 to $140 \mathrm{~km}$ (see Fig. 1B and 2A). Its wrinkled surface morphology is shaped not only by thrustrelated slope breaks and associated folds, which define a large scale stepping morphology, but is also the result of the different combined manifestations of gravitational and fluid escape processes (e.g. "raft-tectonics" type features, sub-circular collapse depressions, mud volcanoes, salt diapirs; Mulder et al., 2003; Pinheiro et al., 2003; Gutscher et al., 2009b; Zitellini et al., 2009; Terrinha et al., 2009). From a structural point of view, the accretionary wedge corresponds to an eastward thickening

pile of westward thrust sediments (Fig. 2B and C), reaching a maximum thickness of ca. $15 \mathrm{~km}$ near the Gibraltar Straits (Thiebot and Gutscher, 2006; Gutscher et al., 2009a). The thrusts root in a common sub-horizontal to gently east dipping decollement layer, exhibiting an overall geometry complying with on-going eastwards subduction beneath the Gibraltar Arc (Gutscher et al., 2002). During the last $5 \mathrm{Ma}$, the E-W convergence rate implied in such a subduction is thought to have diminished from ca. $2 \mathrm{~cm} / \mathrm{year}$ to $0.5 \mathrm{~cm} /$ year (Gutscher et al., 2009a), with a consequent decrease in the activity of the 
wedge thrusts during this time span. Accordingly, the same authors argue that the present internal deformation is preferentially accommodated by small increments of local reactivation of inherited blind thrusts, being more homogeneously distributed over the entire wedge, rather than concentrated on newly formed major frontal thrusts.

The morphologic expression of the SWIM faults corresponds to a continuous alignment of seafloor crests and troughs, sometimes exhibiting an en-échelon geometrical disposition, and commonly punctuated by active mud volcanoes within the domain of the accretionary wedge (see Fig. 1B; Duarte et al., 2009; Terrinha et al., 2009; Zitellini et al., 2009). This overall linear morphology is more prominent both close to the northern part of the GCAW front and in the Horseshoe Valley, where lineaments can be followed almost continuously for more than 200 kilometers (e.g. SWIM 1 in Fig. 1B and 3A). The available reflection seismic dataset in the study area shows that SWIM faults correspond to aligned arrays of deep-rooted faults, often breaching out through the present seafloor sediments and showing extensive evidence for associated fluid migration (e.g. seismic blanking along fluid extrusion paths in Fig. 3B and C; Rosas et al., 2009; Terrinha et al., 2009). From the inspection of the IAM 4 and 3 seismic profiles in figure 3, it is apparent that the SWIM faults are aligned along basement pre-existent (Mesozoic) faults (dashed black lines in Fig. 3; see also Duarte et al., 2009 and Terrinha et al., 2009). Analog modeling of sets of en-échelon folds formed in soft-cover sediments overlying some of the SWIM basement dextral strike-slips (Rosas et al., 2009) yielded an age for their activity of ca. 1.8 Ma.

\subsection{The SWIM-GCAW interference area}

The critical area to understand the interference between the SWIM strike-slips and the GCAW is close to its deformation front (Fig. 4A). Along this front, from north to south, 
three interference sub-areas were thoroughly analyzed (B to D in Fig. 4). The SWIM 2 fault intersects a northern segment of the GCAW front (Fig. 4B) in the vicinity of the Sagres Valley, at an angle of about $40^{\circ}$. Within the thrust wedge to the east, the morphological expression of the SWIM 2 is well marked by a slightly arched trough that splays in the same direction. Conversely, in the Sagres Valley it is almost indiscernible due to the widespread presence of scours and slumps, and it is only detectable by the presence of a gentle slope break. In this area no offset of the wedge deformation front is observed, instead only a small wrinkled WNW-ESE elongate bulge can be detected in the bathymetry of the frontal GCAW (see Fig. 4B). The SWIM 1 fault exhibits a clear morphological expression in the Horseshoe Valley, intersecting the wedge deformation front just to the north of the Coral Patch Ridge, at an angle of about $70^{\circ}$ (Fig. 4C). Its continuation to the east is less visible, although punctuated by mud volcanoes. Similarly to what was described for the SWIM 2 fault, there is no bathymetric evidence for the offset of the wedge front by the SWIM 1 fault. The SWIM 3 fault cuts along the southern flank of the Coral Patch Ridge with a strong morphological imprint (Fig. 4D), corresponding to a lineament marked by several elongated WNW-ESE ridges, troughs and slope breaks. To the east, this lineament crosses a small portion of the Seine Abyssal Plain and intersects the accretionary wedge deformation front, at an angle of about $80^{\circ}$. In this location the wedge front is marked by a slight embayment. On the wedge surface to the north of the fault and parallel to it, an elongated protuberance is also unmistakably observed, limited by two descending slope breaks and vanishing progressively towards the east. As in the two cases described above, the observed morphology does not account for any kind of fault offset overprint relationships. 


\section{Analog Modeling}

Our objective is to test several simple chronological possibilities of mechanical interference between a strike-slip fault and a thrust wedge front, under model conditions comparable to the ones governing the SWIM-GCAW tectonic interference. Three main experiments were carried out to investigate the different deformation patterns resulting from: a) A thrust wedge developed on top of an inactive basement (strike-slip) fault; b) An active dextral strike-slip fault affecting an inactive thrust wedge; c) The simultaneous alternate activity of a thrust wedge front and a dextral strike-slip fault. Experiments were performed to respect the general, simplified, geometry, kinematics and rheology ascribed to the natural strike-slip (SWIM) system and to the (GCAW) thrust wedge. However, analog modeling with dry granular materials cannot reproduce all the complex processes (e.g. fluid overpressure and expulsion, sedimentary deposition, and local gravitational instabilities) which occur in submarine environments. Nevertheless, the regional kinematic and relative timing caused by the local tectonic driving forces and the ensuing structural evolution can be well investigated.

\subsection{Experimental method}

\subsubsection{Material properties and scaling}

The material used as an analog of the GCAW sedimentary rocks was dry quartz sand, whose properties are summarized in Table 1. Sand is considered a Coulomb material deforming in a brittle way according to the Coulomb fracture criterion (e.g. Hubbert, 1937, 1951; Davis et al., 1983, Appendix A), and it has been extensively used in scaled model experiments simulating similar brittle deformation in the upper crust 
(e.g. Mandl et al., 1977; Mulugeta, 1988; Casas et al., 2001; Marques and Cobbold, 2002).

The present models were properly scaled according to the scale model theory of Hubbert (1937). The assumed model - prototype ratios are presented in Table 1, and the detailed procedure of scaling is specified in Appendix A

\subsubsection{Apparatus and initial stage}

Experiments were done using a rectangular $100 \mathrm{~cm} \times 60 \mathrm{~cm}$ Perspex deformation rig, comprising two laterally juxtaposed basal plates and a moving backstop (Fig. 5A). In the initial stage of the experiments, $1 \mathrm{~cm}$ thick layered sand cake was built on top of the basal rigid plates by pouring batches of differently colored sand from a moving elongated funnel, guaranteeing the leveling of its top surface. The basal plates in the model move laterally relatively to each other, and account for the natural basement beneath the thrust wedge decollement (see Fig. 2C). The vertical contact plane between these plates complies with the dominant WNW-ESE orientation of the SWIM 1 fault system (see Fig. 1 and 4). The model sand cake corresponds to the overlying cover sediments, in which accretion is simulated by pushing against it a backstop that slides on top of both basal plates. The backstop lacks any kind of correspondence with any natural feature, and was exclusively used to produce a classical model thrust wedge. Likewise the $(\sim 0.2 \mathrm{~cm}$ thick) layering in the sand cake has also no correspondence with any natural structures, and was used merely as a 3D passive strain marker. In all experiments the dimensions of the deformation rig were sufficiently large to guarantee that the bulk of the model was not affected by boundary conditions. The experiments were repeated several times to ensure the reproducibility of the obtained results. Top 
view photographs were taken at regular time intervals. The final stage of the model was humidified and serially sectioned for three-dimensional analysis.

\subsubsection{Procedure}

Three main experiments were carried out to study three basic possibilities of mechanical interference between a strike-slip basement fault and a thrust wedge:

1) Active thrust wedge and inactive basement fault: the backstop was initially pushed against the sand-cake, on top of the two immobile basal plates.

2) Active basement fault and inactive thrust wedge: after a thrust wedge was previously formed in the sand, the basal plates were dextrally moved relatively to each other.

3) Active basement fault and active thrust wedge: the reactivation of a previously formed thrust wedge was successively alternated with the right-lateral movement between the basal plates.

\subsection{Experimental results}

3.2.1. Experiment 1: active thrust wedge and inactive basement fault

Up until $\sim 30 \%$ of shortening a thrust wedge was classically obtained, through the forward propagation of regularly spaced thrusts, as a result of moving the backstop to the left (see Fig. 5B and Fig. 6A). For a shortening of $31 \%$ (Fig. 6A) the front of the accretionary wedge developed an embayment coinciding with the direction of the 
inactive basement fault (yellow dashed line in Fig. 6A). For a shortening of $38 \%$ a new thrust ( $\mathrm{n}+1$ in Fig. $6 \mathrm{~B}$ ) was formed exclusively to the north of that basement discontinuity. Only when the shortening reached $39 \%$, did the equivalent new thrust form to the south, resulting in a misleading left-lateral offset geometry (yellow arrows in Fig. 6C), in spite of the total absence of relative movement between the two basal rigid plates. For a shortening of $48 \%$ this false offset in front of the newer thrust disappeared (Fig. 6D). In the wedge lower area a linear southeastward splaying, slightly anastomosing, deformation pattern (white lines in Fig. 6D) was progressively developed as shortening accumulated and new outward thrusts successively formed.

\subsubsection{Experiment 2: active basement fault and inactive thrust wedge}

After $48 \%$ of shortening the basement strike-slip fault was activated with dextral movement (Fig. 7) When the horizontal displacement between the basal plates reached only $0.2 \mathrm{~cm}$, a thin elongated bulge formed coinciding with the basement strike-slip direction (Fig. 7A). At this stage no offset of the thrust wedge was observed. A further right-lateral displacement of $0.6 \mathrm{~cm}$ between the basal plates clearly offset the thrust wedge, preferably affecting its frontal outer thrust (Fig. 7B). For a displacement of 1.3 $\mathrm{cm}$ the strike-slip fault seemingly propagated inwards, but only across the following three thrusts (Fig. 7C-D). The resultant model deformation pattern always showed the preferential offset of the frontal thin part of the accretionary wedge, relative to its innermost domains that remained unaffected.

\subsubsection{Experiment 3: active basement fault and active thrust wedge}

After the formation of a thrust wedge due to $47 \%$ of shortening, a right-lateral displacement of $1 \mathrm{~cm}$ was applied to the basal plates (Fig. 8A). As a result, a linear bulge 
formed in the sand foreland, along the strike-slip direction, cutting across the thrust wedge and offsetting its front. Similarly to experiment 2, the amount of right-lateral displacement diminished towards the thicker inner part of the wedge. Subsequently, another $0.4 \%$ of incremental shortening was applied to the model (Fig. 8B). As a result, a new frontal thrust formed, but only to the north of the strike-slip fault. The resultant geometry mimics a false left-lateral offset of the outer frontal thrust (apparent as $n+1$ in Fig. 8B), although careful consideration of the propagation chronology of the thrusts revealed a true dextral offset (affecting thrust $\mathrm{n}$ in Fig. 8B), complying with the underlying basement fault kinematics. Further 1\% of applied shortening (Fig. 8C) produced the new thrust $(n+1)$ also to the south of the strike-slip fault, erasing the previously formed false offset. Another $3.5 \mathrm{~cm}$ of dextral strike-slip displacement was additionally applied to the basal plates (Fig. 8D), and as a consequence, the wedge front was once more kinematically truly dextrally offset. Riedel faults formed on the wedge surface displaying a clear en-échelon spatial disposition, and interfering with the preexistent stepping morphology associated with the thrust stacking. Finally, after another $2.6 \%$ of shortening (Fig. 9), reaching a total accumulated amount of $51 \%$, the frontal wedge offset was once again almost completely attenuated, although the total accumulated basal strike-slip displacement was of $4.5 \mathrm{~cm}$ (corresponding to $22.5 \mathrm{~km}$ ). It should be noted that the previously formed linear en-échelon pattern was preserved in the wedge surface, including in its innermost domain.

\section{Discussion}

Experiment 1 shows that an active thrust wedge forming in cover sediments above an inactive basement fault records the resultant mechanical interference in the 
form of a linear, inner splaying, perturbation of the wedge morphological surface (white lines in Fig. 6C-D). This formed as the result of the successive thrust propagation across the basement anisotropy, which behaved as a mechanical obstacle for the lateral propagation of the frontal thrust. Since this basement anisotropy remains stationary relatively to an external reference frame, and the thrust front propagates forward (to the left), the resultant interference area between both these features migrates from the lower periphery of the thrust front to its central domain (compare the position of the linear perturbation pattern in Figs. 6A to D). Comparison with the natural example shows that the observed inner splaying lineaments in the GCAW (see SWIM 1 in Fig. 1B and SWIM 2 in Fig. 4B), could have originated simply as a consequence of preexisting inactive basement faults. This agrees with the fact that these lineaments are observed in the inner thicker part of the natural thrust wedge, in the complete absence of offset of its thinner frontal part.

Experiment 2 shows that an active basement strike-slip fault affecting an overlying preexistent thrust-wedge, must produce a clear offset of its thinner front, even for minor increments of strike-slip basal displacement $(1.3 \mathrm{~cm}$ corresponding to 6.5 $\mathrm{km})$. This offset vanishes rapidly towards the inner thicker parts of the wedge, affecting almost exclusively the outer frontal thrusts. Comparison with the natural example shows that if the GCAW is presently inactive, and cut by active dextral strike-slip (SWIM) faults, then unambiguous offset of the GCAW front has to exist, which is clearly not the case (see Figs. 1B, 2 and 4).

Experiment 3 shows that if both the basal strike-slip fault and the thrust wedge are active, with alternating incremental fault slips, then the resultant interference deformation pattern can be the cyclic repetition of the following three possibilities: a) true right-lateral offset of the thrust wedge front (see Fig. 8A and D); b) false left-lateral 
offset of the thrust wedge front (see Fig. 8B, similar to experiment 1 see Fig. 6C); c) no offset of the thrust wedge front (see Fig. 8C and 9). It should be noted that the absence of thrust wedge offset does not imply an absence of basement strike-slip displacement, which quite on the contrary is continually increasing. However, the alternation with the incremental shortening that drives the successive forward thrust propagation cyclically erases the offset of the frontal thrust wedge. Differently, the resultant linear en-échelon interference pattern tends to be increasingly well marked, including in the innermost domains of the thrust wedge (compare the lineament in the Figs. 8A and 9). Similarly to experiment 1 , the intermediate experimental stage in which a false left-lateral offset originates (see Fig. 8B), is here interpreted as the result of a delayed propagation of the newer outer thrust across the strike-slip fault, which in accordance seemingly behaves as a mechanical obstacle to such propagation.

In view of these results, and considering the fact that in the natural example the GCAW front is not offset across any of the mapped SWIM faults, one of the two following tectonic scenarios is possible: a) either the GCAW is active, and forming over a basement anisotropy (inactive SWIM fault?); or b) both the GCAW and the SWIM faults are active. The possibility of an inactive GCAW being cut by active dextral strike-slip SWIM faults is clearly ruled out by the present experimental results.

\subsection{Tectonic implications}

The west Mediterranean tectonic evolution comprised the Mesozoic opening of the Tethys Ocean (Fig. 10A; e.g. Maldonado et al., 1999; Gutscher et al., 2002; Gràcia et al., 2003a; Stampfli et al., 2002; Jiménez-Munt et al., 2010). This would account for a basement tectonic anisotropy, hypothetically, either consisting in previous transform 
faults, or in rift-related normal faults (Fig. 10A and B). In view of the presented experimental results, the accretionary wedge (GCAW) is here interpreted to have formed on top of such basement faults (present day SWIM faults) as a consequence of roll-back subduction beneath Gibraltar. During this period (Middle Miocene to $\sim 1.8 \mathrm{Ma}$, Figs. 10C to E) these faults were probably inactive, although capable of originating a linear-like perturbation in the GCAW surface morphology (experiment 1). At same time, the main regional convergence direction between Iberia and Africa gradually suffered a counterclockwise rotation, shifting from N-S (Fig. 10 B) to near WNW-ESE (Fig. 10E). Such reorientation is interpreted to have triggered (since at least $\sim 1.8 \mathrm{Ma}$ ) a dextral strike-slip reactivation of the basement (SWIM) faults (Fig. 10F), during a period in which the subduction driving the GCAW growth was still active (experiment 3), although slowing down (Gutscher, 2009a). It should be noted that this rotation of the main convergence direction also agrees with the general strain partitioning tectonic scenario previously proposed by Terrinha et al. (2009), according to which besides dextral strike slip faulting along near E-W orientated faults, northwest directed thrusts also occur along NE-SW orientated tectonic structures (e.g. Horseshoe, Marquês de Pombal and Gorringe Faults in Fig. 1B).

Other indirect evidence supporting present simultaneous activity of SWIM and GCAW includes the fact that not only all known mud volcanoes in the Gulf of Cadiz are located on top of the accretionary wedge, but also the circumstance that most of the deep mud volcanoes are symptomatically aligned and coincident with the SWIM faults (Fig. 1A). This suggests that the fluid migration and escape may be simultaneously controlled by the activity of both structures. If that is in fact the case, then the mud volcanoes could be preferentially located at the intersection between the SWIM strike- 
slip and the GCAW thrust faults, with such loci providing good pathways for the fluid to ascend (Pinheiro et al., 2003, 2005; Duarte et al., 2005; Rosas et al., 2009; Zitellini et al., 2009; Terrinha et al., 2009).

\section{Conclusions}

1. In view of the presented experimental results, the observed morphotectonic pattern of the frontal GCAW area is compatible with:

i) The development of the GCAW on top of inactive, previously formed, basement faults (present day SWIM fault system).

ii) The simultaneously (alternating) activity of the GCAW thrusting with the activity of the SWIM-related dextral strike-slip faults.

Conversely, the comparison of the same experimental results with the natural example unambiguously excludes the possibility of active strike-slip faulting (SWIM system) affecting an inactive preexistent GCAW, implying that if the SWIM fault system is active then the GCAW must also be presently active.

2. The main tectonic implications of the above conclusions comprise an initial (Middle Miocene to $\sim 1.8 \mathrm{Ma}$ ) accretion of the GCAW sediments on top of preexistent Tethyan rift-related faults, preceding strike-slip reactivation of these faults (SWIM system), simultaneously with decreasing GCAW activity $(\sim 1.8$ 
Ma to present), as a function of counterclockwise rotation of the main IberiaNubia convergence direction.

3. The modeling and morphological observations favor the interpretation of the SWIM fault system as the strike-slip reactivation of pre-existent basement faults. This suggests that the SWIM plate boundary proposed by Zitellini et al. (2009) may in fact correspond to the local reactivation of the older Tethyan plate boundary

\section{Acknowledgments}

This work was sponsored by ALMOND (Multiscale modeling of deformation in the Gulf of Cadiz, PTDC/CTE-GIN/71862/2006 ), EUROMARGINS SWIM (Earthquake and Tsunami hazards of active faults at the South-West Iberian Margin: deep structure, high-resolution imaging and paleo-seismic signature, REN2002-11234EMAR, 01-LEC-EMA09F), TOPOEUROPE/0001/2007-TOPOMED (Plate reorganization in the western Mediterranean: lithospheric causes and topographic consequences) and NEAREST (Integrated observations from NEAR shore sourcES of Tsunamis: towards an early warning system, ESF EuroMargins Program, contract n. 01LEC-EMA09F and from EU Specific Programme "Integrating and Strengthening the European Research Area”, Sub-Priority 1.1.6.3, “Global Change and Ecosystems”, contract n. 037110) projects. Experiments were performed in the Analog Modeling Laboratory of IDL. J. Duarte and S. Silva thank FCT for the PhD grants SFRH/BD/31188/2006 and SFRH/BD/46227/2008, respectively. The support by Landmark Graphics Corporation via the Landmark University Grant Program and 
NASA WorldWind is also acknowledged. We specially thank Stephane Dominguez (University of Montpellier), Sandy Cruden and David Boutelier (Monash University) and Vasco Valadares (LNEG) for insightful discussions. Ruth Keppler, Ana Costa, André Blanco and Liliana D'Almeida are acknowledged for their help in the lab.

\section{Appendix A}

The material used as an analog of the upper crust sedimentary rocks was dry quartz sand, which is considered a Coulomb material deforming in a brittle way according to the Coulomb fracture criterion (e.g. Hubbert, 1937, 1951; Davis et al., 1983):

$$
\tau_{s s}=\mu_{c} \sigma_{n}+c_{0}(1)
$$

where $\tau_{s S}$ is the shear stress, $\mu_{c}$ is the coefficient of internal friction $\left(\mu_{c}=\tan \phi\right.$, and $\phi=$ internal friction angle), $\sigma_{n}$ is the normal stress, and $c_{0}$ is the cohesion of the material. According to the scale model theory (Hubbert, 1937), proper scaling is achieved when the ratios between model and natural prototype are independently established for the three fundamental units of length $(\lambda)$, time $(\tau)$ and mass $(\mu)$ :

$$
\lambda=\frac{L_{(m)}}{L_{(p)}} ; \tau=\frac{T_{(m)}}{T_{(p)}} ; \mu=\frac{M_{(m)}}{M_{(p)}}(2)
$$

where $L=$ length, $T=$ time and $M=$ mass, and $(m)$ stands for model and $(p)$ for natural prototype. The Coulomb fracture criterion governs time independent deformation of brittle materials like sedimentary upper crustal rocks, since yield stress is insensitive to 
the rate of deformation provided that the inertial forces are negligible, as in the present case. This means that $\tau$ ratio is not needed for scaling in this situation. Length ratio $(\lambda)$ was chosen given the maximum dimensions of the deformation apparatus used in the experiments (see section 3), and was conveniently established as $\lambda=2 \times 10^{-6}$. In the present case, of the two relevant material properties, coefficient of internal friction $\left(\mu_{c}\right)$ and cohesion $\left(c_{0}\right)$, the first is dimensionless, and approximately the same in both model and prototype, whereas the second has dimension of stress and thus must be scaled accordingly (Hubbert, 1937):

$$
\Sigma=\frac{c_{0(m)}}{c_{0(p)}}=\frac{\mu \gamma}{\lambda^{2}}
$$

where $\Sigma$ and $\gamma$ are the model/prototype ratio for stress and for acceleration respectively. Since inertial forces are negligible when compared with gravity,

$$
\gamma=\gamma_{g}=\frac{g_{(m)}}{g_{(p)}}=\frac{\lambda}{\tau^{2}}=1(4)
$$

where $\gamma_{g}$ is the model/prototype gravity acceleration ratio. Thus, substituting $\gamma=1$ in equation (3) allows the following simplification:

$$
\Sigma=\frac{c_{0(m)}}{c_{0(p)}}=\frac{\mu}{\lambda^{2}}=\frac{\mu \lambda}{\lambda^{3}}=\delta \lambda
$$

where $\delta$ corresponds to the model/prototype density ratio. Substituting $\delta$ and $\lambda$ in equation (5) by the respective values in Table 1 , immediately allows the determination 
of the implied mass ratio $=4 \times 10^{-18}$. It should also be noted that since $\delta$ is generally close to one (between 0.5 and 0.7 , e.g. Withjack et al., 2007) the strength of the materials expressed by $\Sigma$ is scaled with the lengh $(\lambda)$. Given the fact that in the present case $\lambda=2 \times 10^{-6}$ and since cohesion for upper crustal rocks is clearly typically less than $50 \mathrm{MPa}$, it becomes immediately evident the utility of model materials with very low cohesion $(<100 \mathrm{~Pa})$, such as dry quartz sand, as analogs of upper crustal rocks.

\section{References}

Abe, K., 1979. Size of Great Earthquakes of 1837-1974 Inferred from Tsunami Data. Journal of Geophysical Research, 84 (NB4), 1561-1568

Argus, D.F., Gordon, R.G., DeMets, C., Stein, S., 1989. Closure of the Africa-EurasiaNorth America plate motion circuit and tectonics of the Gloria Fault. Journal of Geophysical Research B, Solid Earth and Planets 24, 5585-5602. doi:10.1016/j.marpetgeo.2007.11.008.

Baptista, M.A., Heitor, S., Miranda, J.M., Miranda, P.M.A., Mendes Victor, L., 1998. The 1755 Lisbon tsunami; evaluation of the tsunami parameters. Journal of Geodynamics 25 (1-2), 143-157.

Baptista, M.A., Miranda, J.M., Chierici, F., Zitellin,N., 2003.Newstudyof the 1755 earthquake source based on multi-channel seismic survey data and tsunami modeling. Natural Hazards and Earth System Sciences 3, 333-340.

Buforn, E., Udias, A., Colombas, M.A., 1988. Seismicity, source mechanisms and tectonics of the Azores-Gibraltar plate boundary. Tectonophysics 152 (1-2), 89-118. 
Calais, E., DeMets, C., Nocquet J.-M., 2003. Evidence for a post-3.16-Ma change in Nubia-Eurasia-North America plate motions? Earth and Planetary Science Letters 216, $81-92$.

Casas, A.M., Gapais, D., Nalpas, T., Besnard, K., Román-Berdiel, K., 2001. Analogue models of transpressive systems. Journal of Structural Geology. 23, 733-743.

DeMets, C., Gordon, R.G., Argus, D.F., Stein, S., 1994. Effect of recent revisions to the geomagnetic reversal time scale on estimates of current plate motions. Geophysical Research Letters 21 (5), 2191-2194.

Duarte, J.C., Rosas, F., Pinheiro, L.M., Matias, L.M., Carvalho, A.M., Terrinha, P., Ivanov, M., 2005. Interpretation of recent sedimentary and tectonic structures off SW Iberia from multibeam bathymetry, seismic reflection and experimental modelling. in: Geophysical Research Abstracts, vol. 7, 07867. European Geosciences Union 2005.

Duarte, J.C., Valadares, V., Terrinha, P., Rosas, F., Zitellini, N., Gràcia, E., 2009. Anatomy and tectonic significance of WNW-ESE and NE-SW lineaments at a transpressive plate boundary (Nubia-Iberia). Trabajos de Geología 29, 237-241.

Duarte, J.C., Terrinha, P., Rosas, F.M., Valadares, V., Pinheiro, L.M., Matias, L., Magalhães, V., Roque, C., 2010. Crescent-shaped morphotectonic features in the Gulf of Cadiz (offshore SW Iberia). Marine Geology 271, 236-249.

Fernandes, R.M.S., Ambrosius, B.A.C., Noomen, R., Bastos, L.,Wortel, M.J.R., Spakman,W., Govers, R., 2003. The relative motion between Africa and Eurasia as derived from ITRF 2000 and GPS data. Geophys. Res. Lett. 30 (16), 1828.

Fernandes, R.M.S, 2004. Present-day kinematics at the Azores-Gibraltar plate boundary as derived from GPS observations. Delft University Press, The Netherlands. 
Fernandes, R.M.S, J.M. Miranda, R.M.L. Meijninger, M.S. Bos, R. Noomen, L. Bastos,B.A.C. Ambrosius and R.E.M. Riva, 2007. Surface velocity field of the IberoMaghrebian segment of the Eurasia-Nubia plate boundary, Geophysical Journal International 169, 315-324.

González, A., Torné, M., Córdoba, D., Vidal, N., Matias, L.M., Díaz, J., 1996. Crustal thinning in the southwestern Iberia margin. Geophysical. Research Letters 23 (18), $2477-2480$.

Gràcia, E., Dañobeitia, J., Vergés, J., Bartolomé, R., 2003a. Crustal architecture and tectonic evolution of the Gulf of Cadiz, SW Iberia, at the convergence of the Eurasian and African plates. Tectonics 22 (4), 1033.

Gràcia, E., Dañobeitia, J., Vergés, J., and the PARSIFAL Team, 2003b. Mapping active faults offshore Portugal (36 degrees N-38 degrees N); implications for seismic hazard assessment along the Southwest Iberian margin. Geology 31 (1), 83-86.

Gutscher, M.A., Kukowski, N., Malavieille, J., Lallemand, S., 1998a. Episodic imbricate thrusting and underthrusting: analog experiments and mechanical analysis applied to the Alaskan accretionary wedge. Journal of Geophysical Research 103, $10161-10176$

Gutscher, M.A., Kukowski, N., Malavieille, J., Lallemand, S., 1998b. Material transfer in accretionary wedges from analysis of a systematic series of analog experiments. Journal of Structural Geology 20, 407-416.

Gutscher, M.-A., Malod, J., Rehault, J.-P., Contrucci, I., Klingelhoefer, F., Spakman, W., Mendes-Victor, L., 2002. Evidence for active subduction beneath Gibraltar. Geology 30 (12), 1071-1074. 
Gutscher, M.A., 2004. What caused the Great Lisbon earthquake? Science, 305(5688): $1247-1248$.

Gutscher, M-A., Dominguez, S., Westbrook, G.K., Leroy, P., 2009a. Deep structure, recent deformation and analog modeling of the Gulf of Cadiz accretionary wedge: Implications for the 1755 Lisbon earthquake. Tectonophysics 475, 85-97.

Gutscher, M-A., Dominguez, S., Westbrook, G.K., Gente, P., Babonneau, N., Mulder, T., Gonthier, E., Bartolome, R., Luis, J., Rosas, F., Pedro T., and the Delila and DelSis Scientific Teams, 2009b. Tectonic shortening and gravitational spreading in the Gulf of Cadiz accretionary wedge: observations from multi-beam bathymetry and seismic profiling. Marine and Petroleum Geology 26, 647-659.

Hubbert, M.K., 1937. Theory of scale models as applied to the study of geologic structures. Geological Society of America Bulletin, 48, 1459-1520.

Hubbert, M.K., 1951. Mechanical basis for certain familiar geologic structures. Geological Society of America Bulletin 62, 355- 372.

Jiménez-Munt I., Fernàndez, M. Vergés, J., Afonso, J.C., Garcia-Castellanos, D., Fullea, J., 2010, The lithospheric structure of the Gorringe Bank: insights into its origin and tectonic evolution, Tectonics, 29, TC5019, doi:10.1029/2009TC002458.

Johnston, A., 1996. Seismic moment assessment of earthquakes in stable continental regions: III. New Madrid, 1811-1812, Charleston 1886 and Lisbon 1755. Geophysical Journal International 126, 314-344.

Lonergan, L. and White, N., 1997. Origin of the Betic-Rif mountain belt: Tectonics, v. 16 , p. $504-522$. 
Malavieille, J., 1984, Modélisation expérimentale des chevauchements imbriqués: application aux chaînes de montagnes : Bulletin de la Société Géologique de France, v. 26, p. 129-138.

Maldonado, A., Somoza, L., Pallarés, L., 1999. The Betic orogen and the IberianAfrican boundary in the Gulf of Cadiz: geological evolution (central North Atlantic). Marine Geology, 155,(1-2), 9-43.

Mandl, G., de Jong, L.N.J. and Maltha, A., 1977. Shear zones in granular material; an experimental study of their structure and mechanical genesis, Rock Mechanics, 9, 95144.

Marques, F.O., Cobbold, P.R., 2002. Topography as a major factor in the development of arcuate thrust belts: insights from sandbox experiments. Tectonophysics 348, 247268.

Martinez-Solares, J.M., López Arroyo, A., 2004. The great historical 1755 earthquake: effects and damage in Spain. J. Seismol. 8, 275-294.

Medialdea, T., Vegas, R., Somoza, L., Vázquez, J.T., Maldonado, A., Díaz-del-Río, V., Maestro, A., Córdoba, D., Fernández-Puga, M.C., 2004. Structure and evolution of the "Olistostrome" complex of the Gibraltar Arc in the Gulf of Cádiz (eastern Central Atlantic): evidence from two long seismic cross-sections. Marine Geolology 209, 173198.

Michard, A., Chalouan, A., Feinberg, H., Goffé, B., Montigny, R., 2002. How does the Alpine belt end between Spain and Moroco?. Bulletin de la Societe Geologique de France 173 (1), p. 3-15. 
Mulder, T., Voisset, M., Lecroart, P., Le Drezen, E., Gonthier, E., the Cadisar Shipboard Party, 2003. The Gulf of Cadiz: an unstable giant contouritic levee. GeoMarine letters 23, 7-18.

Mulugeta, G., 1988. Modelling the geometry of Coulomb thrust wedges. Journal of Structural Geology 10, 847-859.

Nocquet, J.M., Calais, E., 2004. Geodetic measurements of crustal deformation in the western Mediterranean and Europe. Pure and Applied Geophysics. 161 (3), 661-681.

Pinheiro, L., Ivanov, M.K., Sautkin, A., Akhmanov, G., Magalhães, V., Volkonskaya, A., Monteiro, J.H., Somoza, L., Gardner, J., Hamouni, N., Cunha, M.R., 2003. Mud volcanism in the Gulf of Cadiz: results from the TTR-10 cruise. Marine Geology 195, $131-151$.

Rosas, F.M., Duarte, J.C., Terrinha, P., Valadares, V., Matias, L., 2009. Morphotectonic characterization of major bathymetric lineaments in NW Gulf of Cadiz (Africa-Iberia plate boundary): insights from analogue modelling experiments. Marine Geology 261, $33-47$.

Rosas, F.M., Duarte, J.C., Neves, M.C., Terrinha, P., Silva, S., Matias, L.., Submitted. Thrust-wrench interference between major active faults in the Gulf of Cadiz (AfricaEurasia plate boundary, offshore SW Iberia): tectonic implications from analogue and numerical modeling.

Rosenbaum, G., Lister, G.S., Duboz, C., 2002. Reconstruction of the tectonic evolution of the western Mediterranean since the Oligocene. In: Rosenbaum G., Lister G.S., 2002. Reconstruction of the evolution of the Alpine-Himalayan. Orogen. Journal of the Virtual Explorer, 8, 107-126. 
Rosenbaum, G., and Lister, G.S., 2004. Formation of arcuate orogenic belts in the western Mediterranean region, in Sussman, A.J., and Weil, A.B., eds., Orogenic curvature: Integrating paleomagnetic and structural analyses: Boulder, Colorado, Geological Society of America Special Paper 383, 41-56.

Royden, L.H., 1993. Evolution of retreating subduction boundaries formed during continental collision. Tectonics, 12, 629-638.

Sartori, R., Torelli, L., Zitellini, N., Peis, D., Lodolo, E., 1994. Eastern segment of the Azores-Gibraltar line (central-eastern Atlantic): an oceanic plate boundary with diffuse compressional deformation. Geology 22, 555-558.

Sella, G.F., Dixon, T.H., Mao, A., 2002. REVEL; a model for recent plate velocities from space geodesy. Journal of Geophysical. Research 107 (B4), 17.

Stampfli, G. M., Borel, G. D., Marchant, R. \& Mosar, J. 2002. Western Alps geological constraints on western Tethyan reconstructions. In: Rosenbaum, G. and Lister, G. S. 2002. Reconstruction of the evolution of the Alpine-Himalayan Orogen. Journal of the Virtual Explorer, 8, 77 - 106.

Terrinha, P., Pinheiro, L.M., Henriet, J.P., Matias, L., Ivanov, M.K., Monteiro, J.H., Akhmetzhanov, A., Volkonskaya, A., Cunha, T., Shaskin, P. and Rovere, M., 2003. Tsunamigenic-seismogenic structures, neotectonics, sedimentary processes and slope instability on the southwest Portuguese Margin. Marine Geology, 195(1-4): 55-73.

Terrinha, P., Matias, L., Vicente, J.C., Duarte, J., Luís, J., Pinheiro, L., Lourenço, N., Diez, S., Rosas, F.M., Magalhães, V., Valadares, V., Zitellini, N., Mendes-Víctor, L., MATESPRO Team, 2009. Morphotectonics and Strain Partitioning at the Iberia-Africa 
plate boundary from multibeam and seismic reflection data. Marine Geology 267, 156174.

Thiebot, E. and Gutscher, M-A., 2006. The Gibraltar Arc seismogenic zone (part 1): Constraints on a shallow east dipping fault plane source for the 1755 Lisbon earthquake provided by seismic data, gravity and thermal modeling. Tectonophysics $426,135-152$.

Withjack, M.O., Schlische, R.W., Henza, A.A., 2007. Scaled Experimental Models of Extension: Dry Sand vs.Wet Clay. Houston Geological Society Bulletin, 49 (8): 31-49.

Zitellini, N., Mendes, L. A., Cordoba, D., Danobeitia, J., Nicolich, R., Pellis, G., Ribeiro, A., Sartori, R., Torelli, L., Bartolomé, R., Bortoluzzi, G., Calafato, A., Carrilho, F., Casoni, L., Chierici, F., Corela, C., Correggiari, A., Della Vedova, B., Gràcia, E., Jornet, P., Landuzzi, M., Ligi, M., Magagnoli, A., Marozzi, G., Matias, L., Penitenti, D., Rodriguez, P., Rovere, M., Terrinha, P., Vigliotti, L., Zahinos Ruiz, A., 2001. Source of 1755 Lisbon Earthquake and Tsunami Investigated. EOS Transactions, American Geophysical Union, 82(26): 290-291.

Zitellini, N., Rovere, M., Terrinha, P., Chierici, F., Matias, L. and Bigsets Team., 2004. Neogene through quaternary tectonic reactivation of SW Iberian passive margin. Pure and Applied Geophysics, 161(3): 565-587.

Zitellini, N., Gracia, E., Matias, L., Terrinha, P., Abreu, M.A., DeAlteriis, G., Henriet, J.P., Dañobeitia, J.J., Masson, D.G., Mulder, T., Ramella, R., Somoza, L., Diez, S., 2009. The quest for the Africa-Eurasia plate boundary west of the Strait of Gibraltar. Earth and Planetary Science Letters, 280, 1-4, pp: 13-50.

\section{Figure captions}


Fig. 1. (A) Location of the Gulf of Cadiz area in the general tectonic setting of the Eurasia (Iberia) - Africa (Nubia) plate boundary. AGFZ - Açores-Gibraltar Fracture Zone; (B) Simplified tectonic map of the Gulf of Cadiz area (adapted from Duarte et al., 2009, Terrinha et al., 2009, Zitellini et al., 2009 and Duarte et al., 2010; bathymetry from the SWIM compilation; Zitellini et al., 2009). Gulf of Cadiz Accretionary Wedge (GCAW) - dark grey outline; SWIM wrench system according to Zitellini et al. (2009) white lines. Black dots correspond to the location of known mud volcanoes (e.g. Hensen et al., 2007).

Fig. 2. (A) Perspective view (from southwest) of the Gulf of Cadiz Accretionary Wedge surface and adjacent areas; (B) Delsis Multichannel seismic profile across the accretionary wedge deformation front (see Fig. 2A for location) and (C) respective interpretation.

Fig. 3. (A) Perspective view (from southwest) of the SWIM lineaments; (B) Multichannel seismic profiles IAM-4 and IAM-3 crosscutting SWIM fault 1 and (C), and respective interpretation; note the Mesozoic rift-related faults (black dashed lines). $\mathrm{CF}$ - Oblique dextral-reverse faults (Corner Faults of Rosas et al., submitted). See location in Fig. 3A.

Fig. 4. General (A) and detailed (B, C and D) bathymetric imaging and respective morphotectonic interpretation (B', C', and D') of the interference area between the accretionary wedge deformation front and the SWIM 1, 2 and 3 strike-slip faults. Note the absence of offset overprint relationships 
Fig. 5. (A) - Sketch of experimental apparatus and model set-up at initial stage. (B) Model top view after $20 \%$ of shortening.

Fig. 6. Results of Experiment 1: active thrust wedge and inactive basement fault. A, B, C and D - Model top view after 31, 38, 39 and $48 \%$ of shortening, respectively. Yellow dashed line - direction of basement (inactive) fault; White arrow - direction of shortening; Yellow half arrows - apparent left-lateral offset; White lines mark the inner splaying geometry of the wedge surface perturbation; $n, n+1, \ldots n+n$ refer to the relative chronology of thrust propagation in B, C and D. SL (thin black lines) - slip lines (Note that the slip lines are a byproduct of boundary conditions due to backstop finite length).

Fig. 7..Results of Experiment 2: active basement fault and inactive thrust wedge. A,B and C - Model top view after 0.2, 0.6 and $1.3 \mathrm{~cm}$ of right-lateral strike-slip displacement, respectively. D - Perspective view of the deformation stage illustrated in C. E - Orthogonal cross section of the thrusted wedge (see location in D). White half arrows indicate right-lateral offset.

Fig. 8. Results of Experiment 3: active basement fault and active thrust wedge. A,B, C and D - Model top view after different increments of shortening and dextral strike-slip displacements; $\mathrm{n}, \mathrm{n}+1, \ldots \mathrm{n}+\mathrm{n}$ refer to the relative chronology of thrust propagation; White line - dextral strike-slip fault trace ( $\mathrm{R}$ - en-échelon Riedels). White half arrows dextral offset; Yellow half arrows - false left-lateral offset of the frontal wedge thrust. 
Fig. 9. Final stage of Experiment 3: active basement fault and active thrust wedge (continuation). Model top view after $51 \%$ of shortening and $4.5 \mathrm{~cm}$ of dextral strikeslip displacement. Note the practical absence of corresponding offset in the frontal thrust wedge.

Fig. 10. Tectonic model: summarized, schematic representation of the main chronologic events leading to the formation of the present day main tectonic features in the Gulf of Cadiz (stages A to D are adapted from Rosenbaum et al., 2002 and 2004; and complemented with Maldonado et al., 1999; Michard et al., 2002; Gràcia et al., 2003a and Terrinha et al., 2009). Ab - Alboran; Cb - Calabria; Cs - Corsica; Sd - Sardinia. See detailed explanation in the text.

Table 1 - Parameters and material properties 


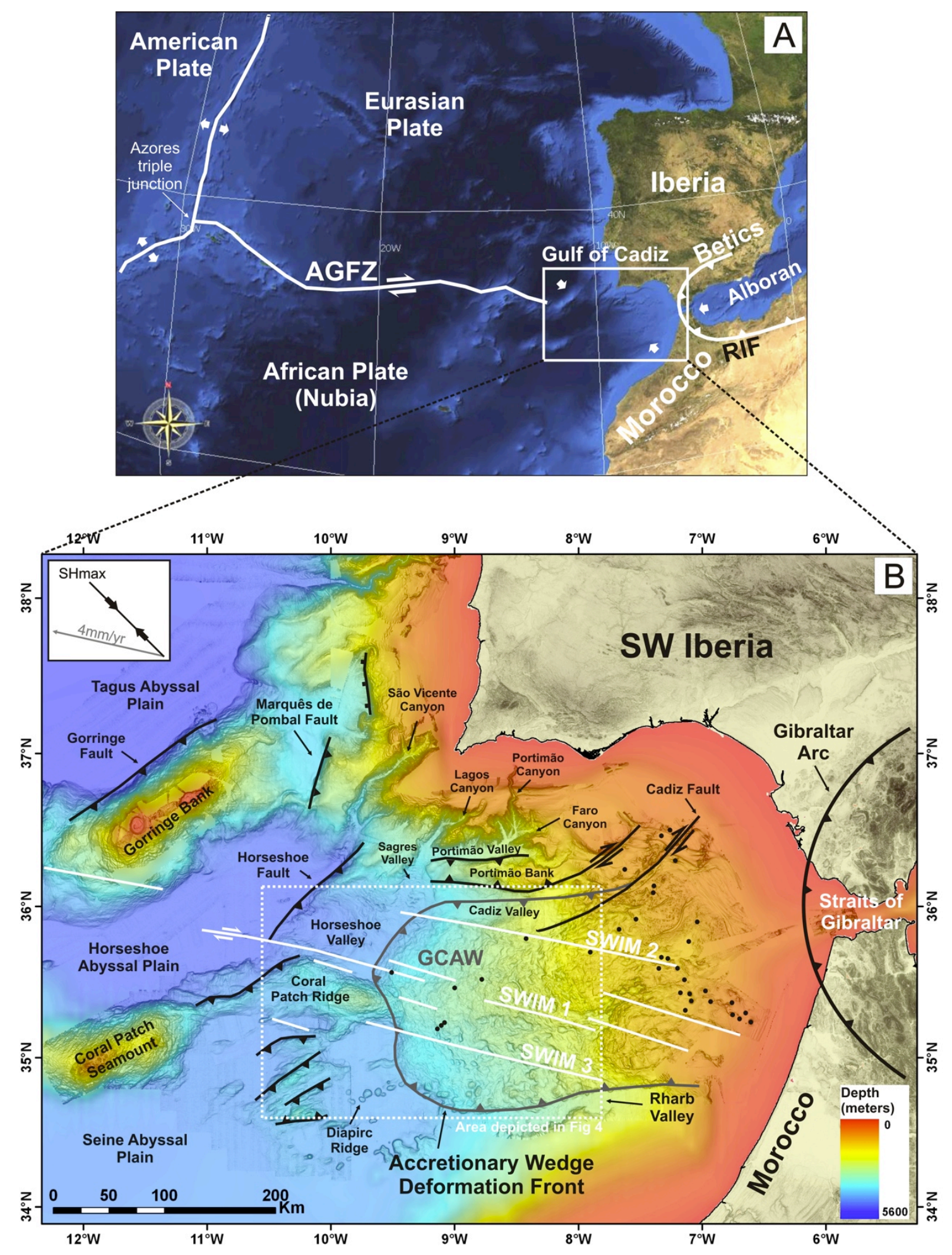

Figure 1 

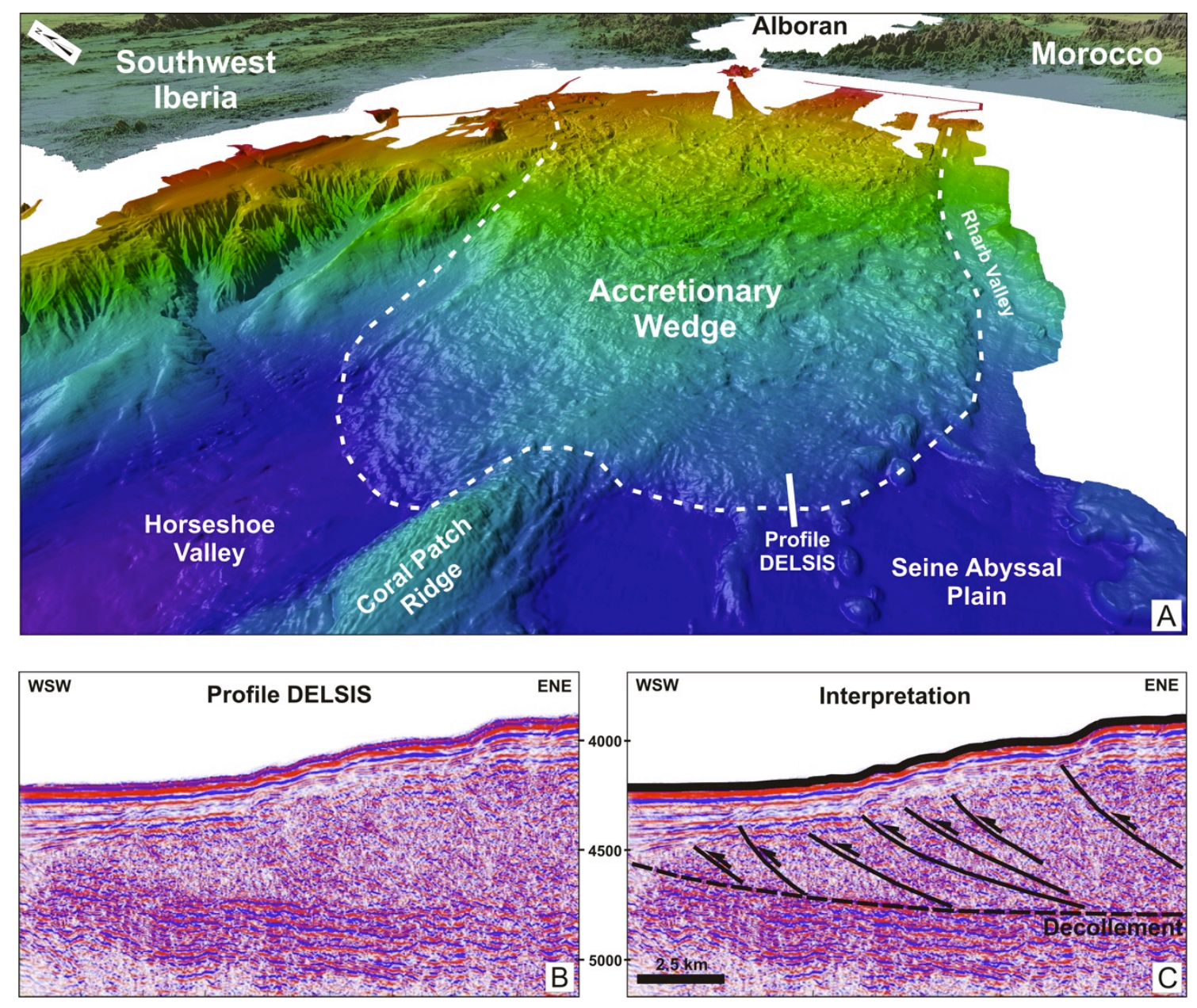

Figure 2 

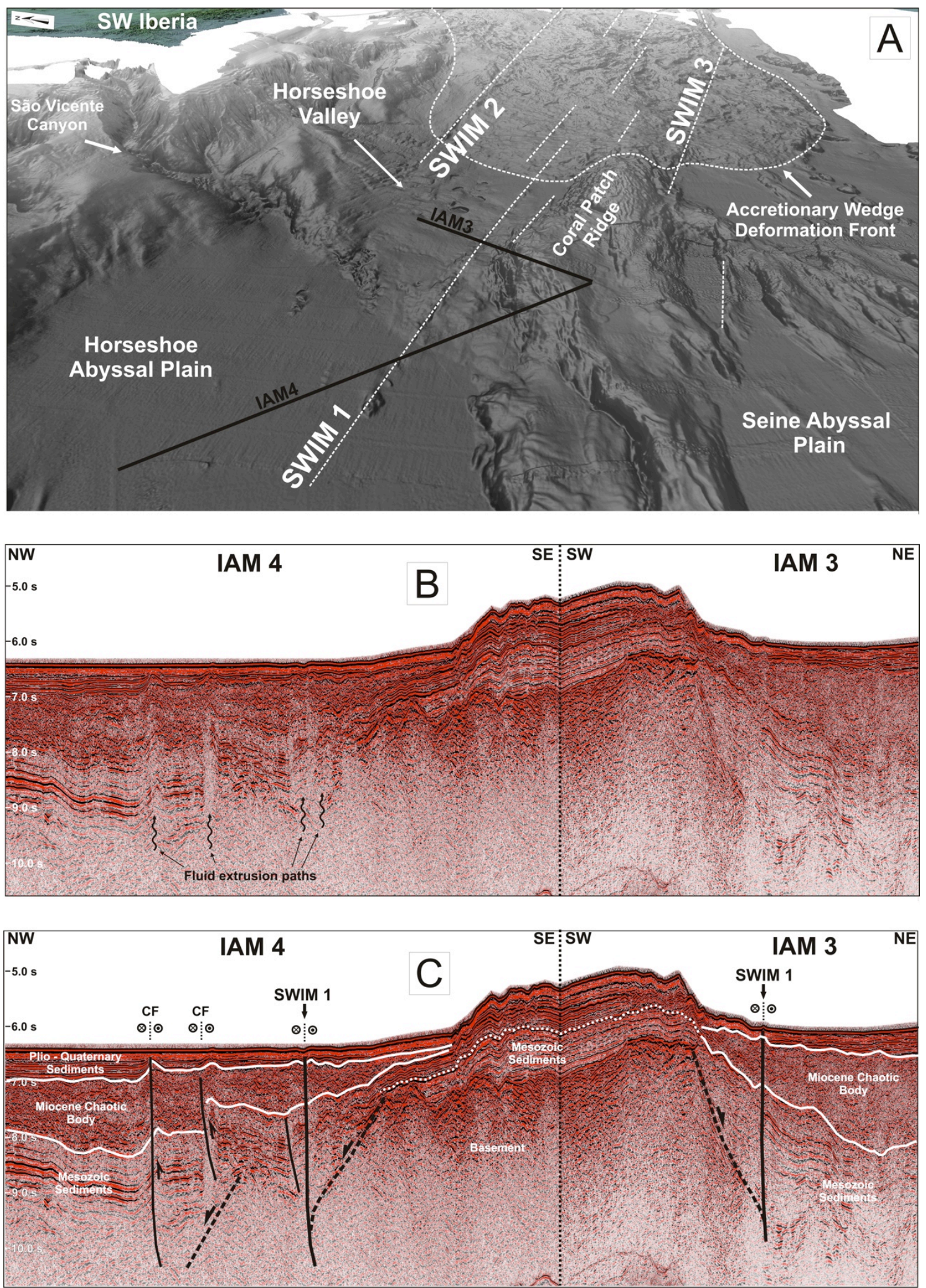

Figure 3 

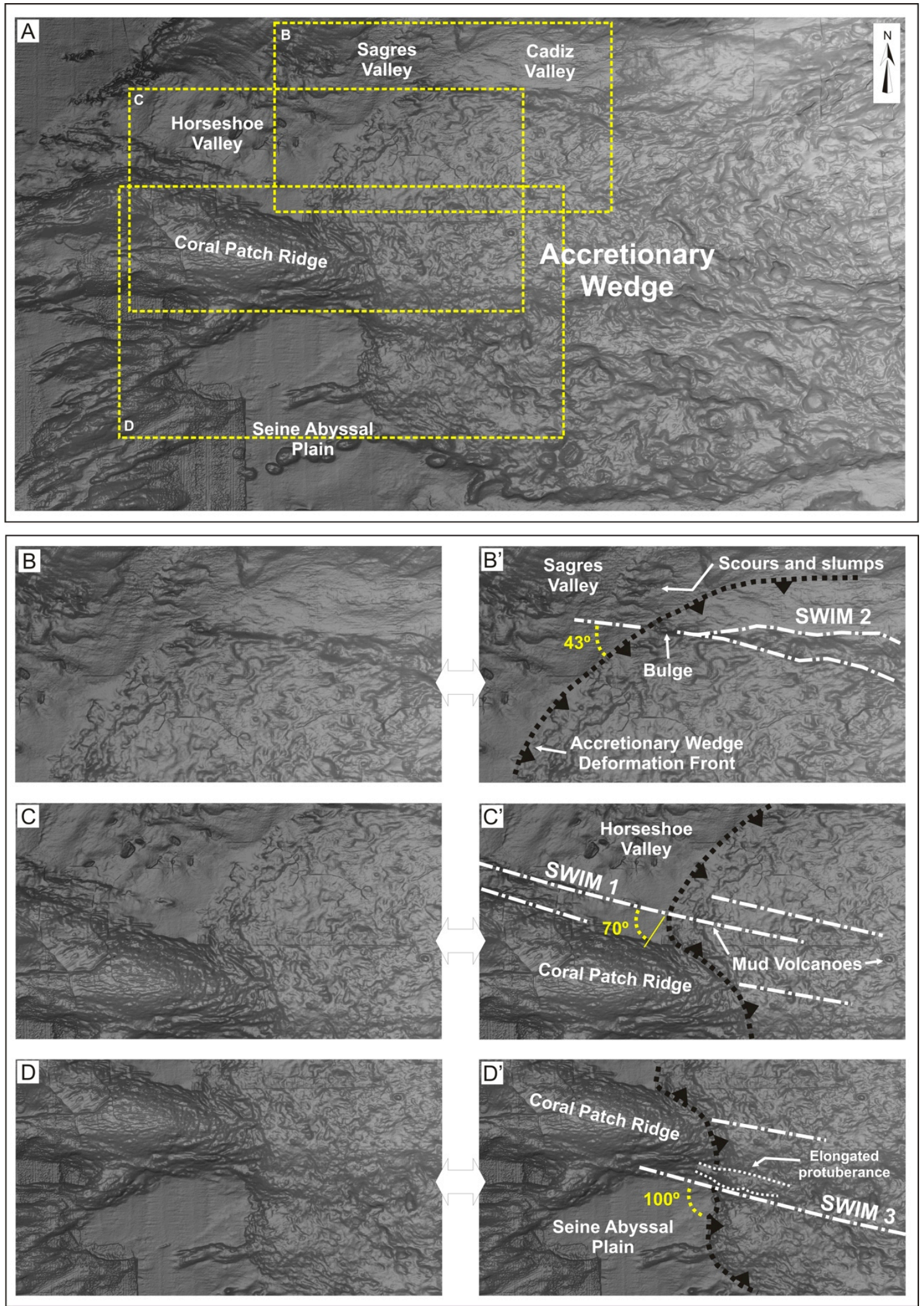

Figure 4 


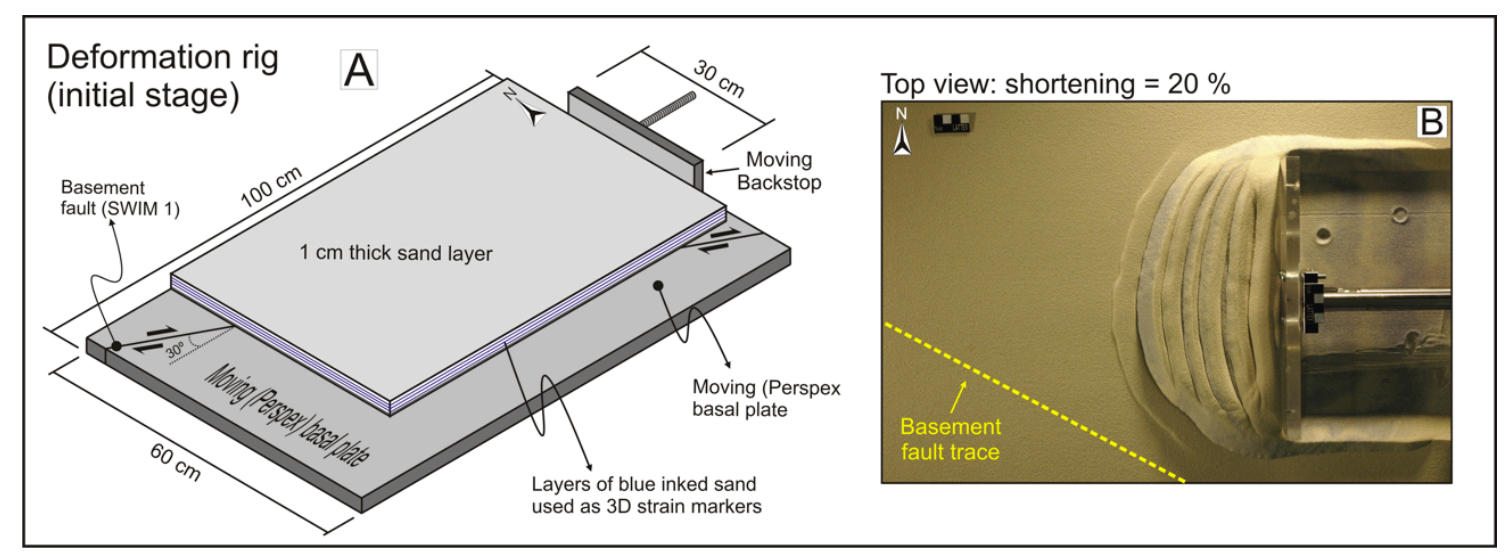

Figure 5

Experiment 1: active thrust wedge and inactive basement fault

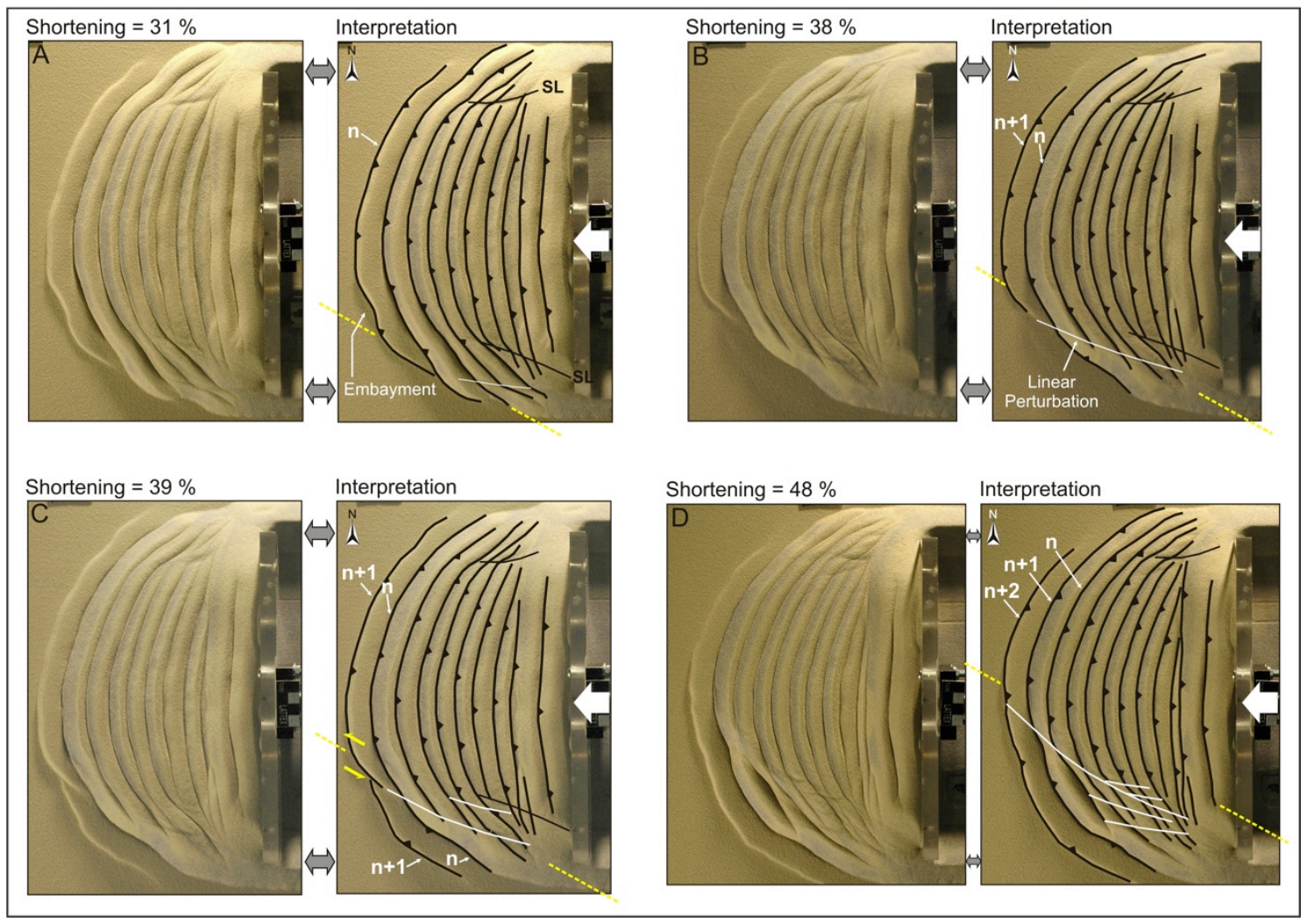

Figure 6 
Experiment 2: active basement fault and inactive thrust wedge

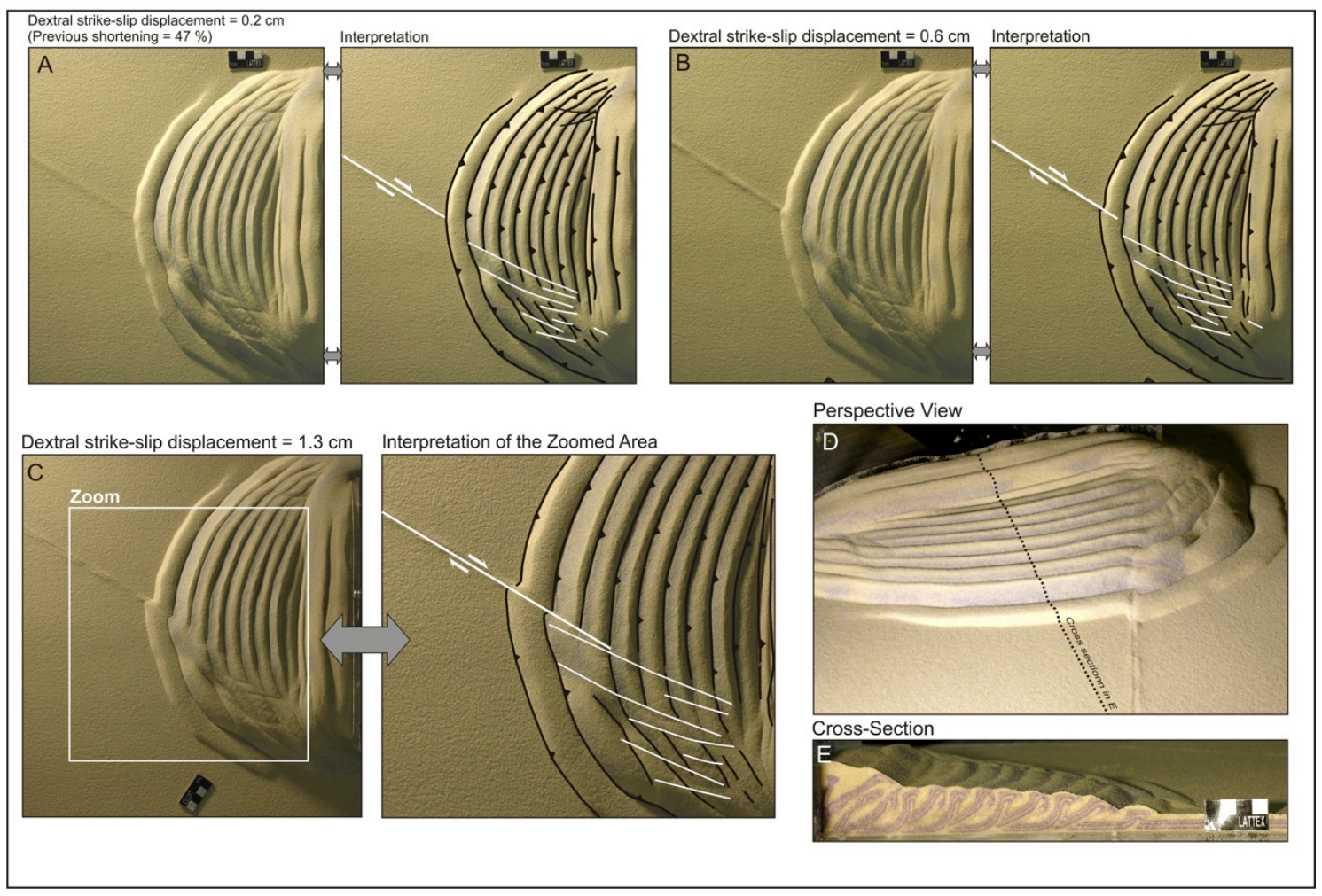

Figure 7

Experiment 3: active basement fault and active thrust wedge
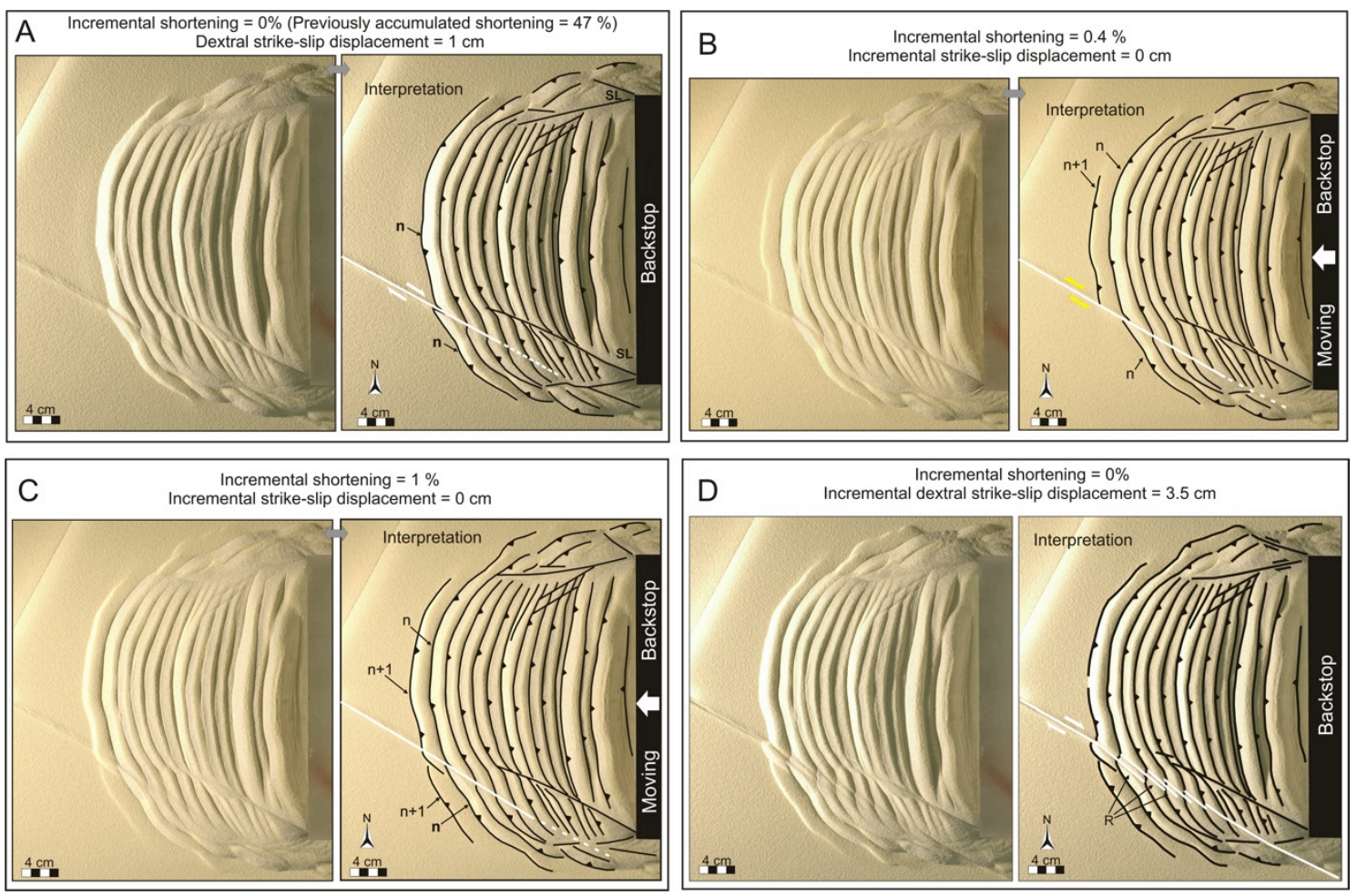

Figure 8 
Experiment 3: active basement fault and active thrust wedge (cont.)

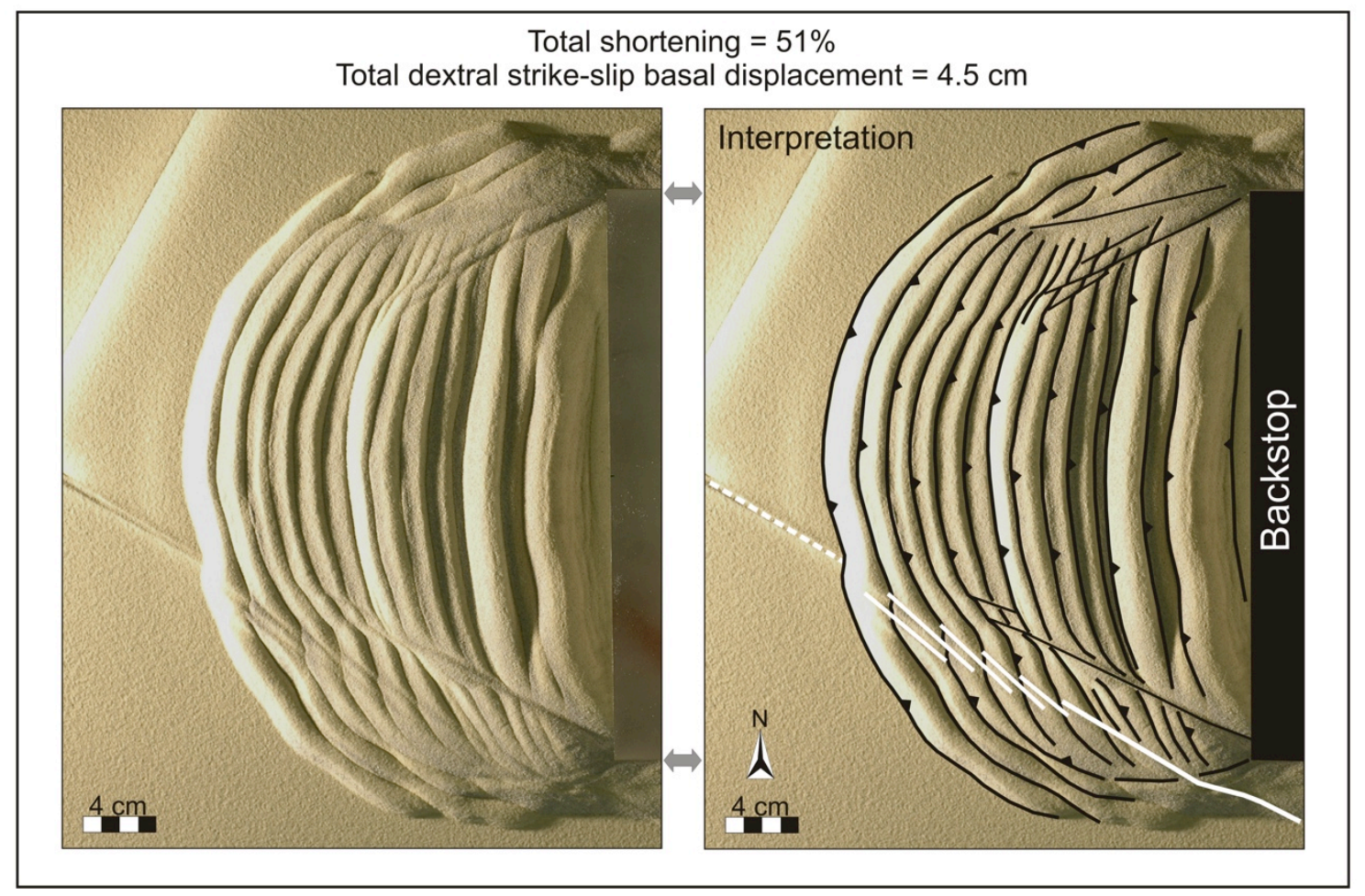

Figure 9 

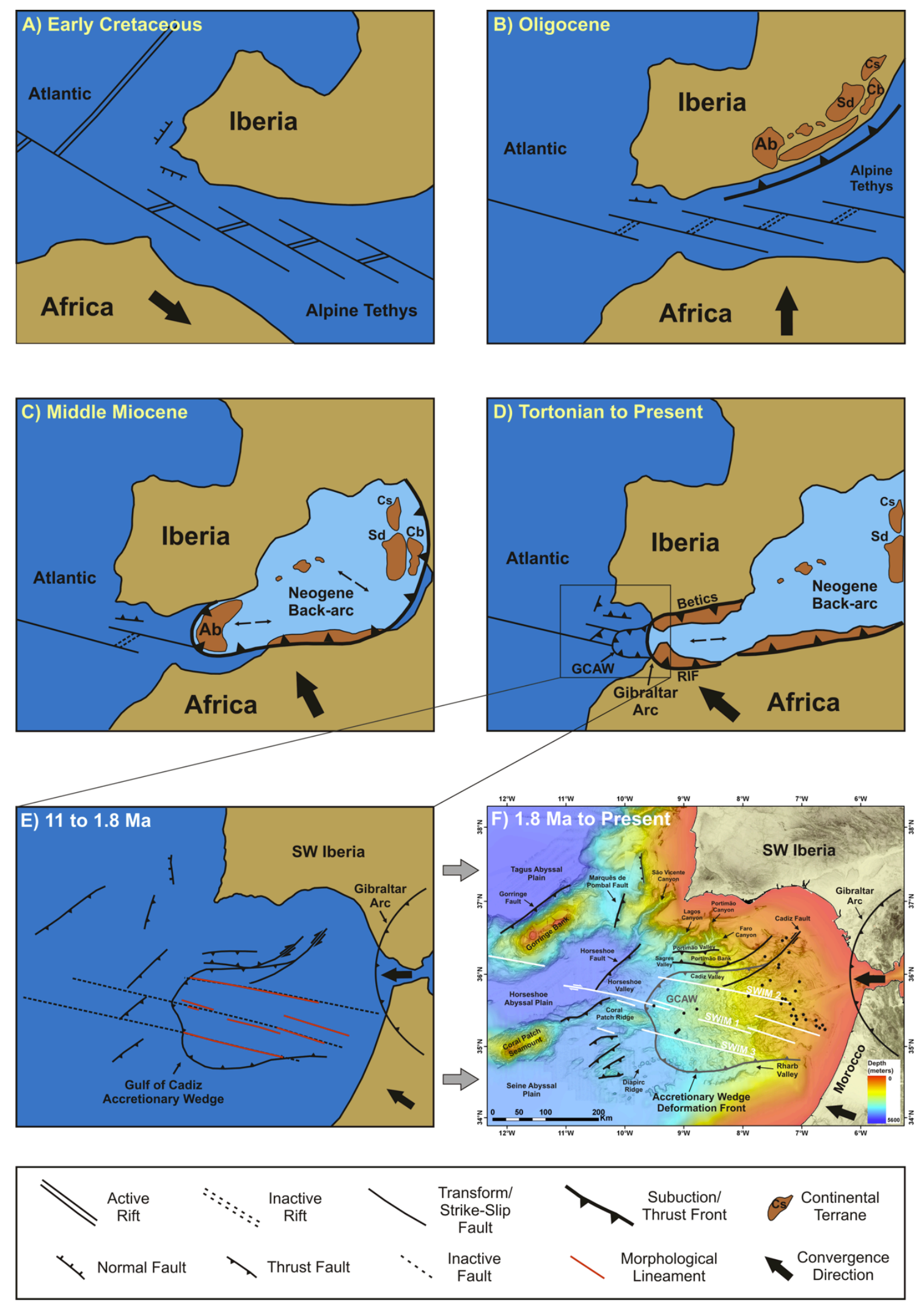

Figure 10

Table 1 


\begin{tabular}{llll}
\hline Parameters and material properties & $\begin{array}{l}\text { Quartz sand } \\
\text { (model) }\end{array}$ & $\begin{array}{l}\text { Natural } \\
\text { prototype }\end{array}$ & $\begin{array}{l}\text { Ratio: } \\
\text { Model/Nature }\end{array}$ \\
\hline Composition (\%) & $99.7 \%$ quartz & - & - \\
Grain shape & $\begin{array}{l}\text { well-rounded } \\
\text { Grain size }(\mathrm{mm})\end{array}$ & - & - \\
Density $\left(\mathrm{kgm}^{-3}\right)$ & $<0.30$ & - & - \\
Internal friction angle, $\phi\left(^{\circ}\right)$ & 1300 & 2600 & $\delta=0.5$ \\
Coefficient of internal friction, $\mu_{\mathrm{c}}$ & $\sim 30$ & - & - \\
Cohesion, $\mathrm{C}_{0}(\mathrm{~Pa})$ & $\sim 0.6$ & $0.6-0.85$ & - \\
Gravity accelaration, $\mathrm{g}\left(\mathrm{ms}^{-2}\right)$ & negligible & $40 \times 10^{6}$ & - \\
Length, L (m) & 9.81 & 9.81 & $\gamma_{\mathrm{g}}=1$ \\
Mass, $\mathbf{M}(\mathrm{Kg})$ & 0.01 & 5000 & $\boldsymbol{\lambda}=\mathbf{2 \times 1 0 ^ { - 6 }}$ \\
\hline
\end{tabular}

Note:

- Scaled fundamental units are in bold

- A mean cohesion of $\mathbf{C}_{\mathbf{o}}=\mathbf{4 0} \mathrm{MPa}$ was assumed from the natural prototype (e.g. Hoshino et al., 1972; Weijermars et al., 1993) 